\title{
Dissolved ion analyses of stream water from bamboo forests: Implication for enhancement of chemical weathering by bamboo
}

\author{
Tasuku AKagi, ${ }^{1 *}$ Misuzu Hayashi, ${ }^{1}$ Yuriko Hara,,${ }^{1}$ Rie TAKada, ${ }^{1}$ Mariko Emoto, ${ }^{1}$ SAKi Yasuda, ${ }^{1}$ \\ YOKO MIYOSHI, ${ }^{1}$ JUN-ICHIRO ISHIBASHI ${ }^{1}$ and SHIGEYUKI SASAKI ${ }^{2}$ \\ ${ }^{1}$ Department of Earth and Planetary Sciences, Faculty of Sciences, Kyushu University, \\ 6-10-1 Hakozaki, Higashi-ku, Fukuoka 812-8581, Japan \\ ${ }^{2}$ Fukuoka Prefecture Forestry Research and Technology Center, \\ 1438-2 Toyoda, Yamamoto-cho, Kurume, Fukuoka 839-0827, Japan
}

(Received December 22, 2011; Accepted October 22, 2012)

\begin{abstract}
Dissolved ion analyses of stream water were conducted monthly in three catchments of varying bamboo coverage of similar geological setting for one year. We found that the concentration of dissolved $\mathrm{Si}$, non-sea salt $\mathrm{Na}, \mathrm{K}, \mathrm{Mg}$, and alkalinity increased with the increase of bamboo coverage and we concluded that bamboo significantly contributes to chemical weathering.

Based on the similar and constant $\mathrm{Cl}$ concentrations in stream water in the three catchments throughout the year, we simplified the system with respect to the evapotranspiration correction and basal runoff influence. Since calcite was not detected in the streambed sediment, non-sea salt $\mathrm{Na}$ and $\mathrm{Ca}$ are assumed to have originated from plagioclase, and thus the plagioclase weathering rate was calculated. The plagioclase weathering rate in bamboo forests was estimated to be more than $1000 \mathrm{~mol} \mathrm{ha}^{-1} \mathrm{yr}^{-1}$ : twice as high as that in a control bamboo-free forest. The dissolved Si export rate of $0.11 \mathrm{~mol} / \mathrm{m}^{2} /$ yr from the two bamboo catchments is greater than that of bamboo-free catchment or reported data from rivers in other parts of the world. We discuss further the Si cycle in bamboo forests, comparing with that of bamboo-free forests.
\end{abstract}

Keywords: weathering rate, plagioclase, dissolved ions, bamboo, stream water

\section{INTRODUCTION}

Chemical weathering involves reactions whereby silicate minerals are disintegrated to ions, clays and secondary quartz or dissolved silica by the action of water and carbon dioxide and other acids in soil (Langmuir, 1997). Because plant roots release carbon dioxide and secrete organic acids in soil, plants may contribute to the reaction to a considerable extent (Berner, 1995; Akter and Akagi, 2005; Moulton et al., 2000). The reaction comprises a unique interplay of the lithosphere, the hydrosphere, the atmosphere and the biosphere (Brantley et al., 2007) and important in controlling the atmospheric $\mathrm{CO}_{2}$ level over a long time scale (Walker et al., 1981; Berner, 1992).

It is well known that some plant species accumulate $\mathrm{Si}$ in their shoots (Ma and Takahashi, 2002). The ultimate origin of the $\mathrm{Si}$ in $\mathrm{Si}$-accumulating plants is doubtlessly silicate minerals in rocks and airborne matter. We question whether Si-accumulating plants contribute to

*Corresponding author (e-mail: akagi@geo.kyushu-u.ac.jp)

Copyright (c) 2012 by The Geochemical Society of Japan. chemical weathering more than plants that don't accumulate $\mathrm{Si}$. Bamboos are $\mathrm{Si}$-accumulating plants with silica $\left(\mathrm{SiO}_{2}\right)$ concentrations as high as 5 to $30 \%$ in dry weight (Motomura et al., 2002; Ma and Takahashi, 2002; Li et $a l ., 2006)$. The contribution of bamboo to chemical weathering is unclear, as bamboo may efficiently absorb the $\mathrm{Si}$ recycled from bamboo litter ( $\mathrm{Li}$ et al., 2006; Fraysse et al., 2006). Recently, the enhancement of silicate weathering by bamboo was postulated based on the slight increase of silicate-derived dissolved ion concentration in water from bamboo forests (Song et al., 2011). Since the concentration may depend on various factors, more studies are needed to support their conclusion. It should be noted that the question of how much bamboo contributes to chemical weathering is essentially how efficiently they recycle $\mathrm{Si}$ from their litter. The former question is primarily of biogeochemical interest and the latter of forestry and ecology interest.

In this study we carried out analyses of stream water from three catchments with different bamboo coverage on a hill, which has been undisturbed by local people for many years, and compared some dissolved components of weathering origin to see if there is any relationship between the concentration and bamboo cover. Significant 


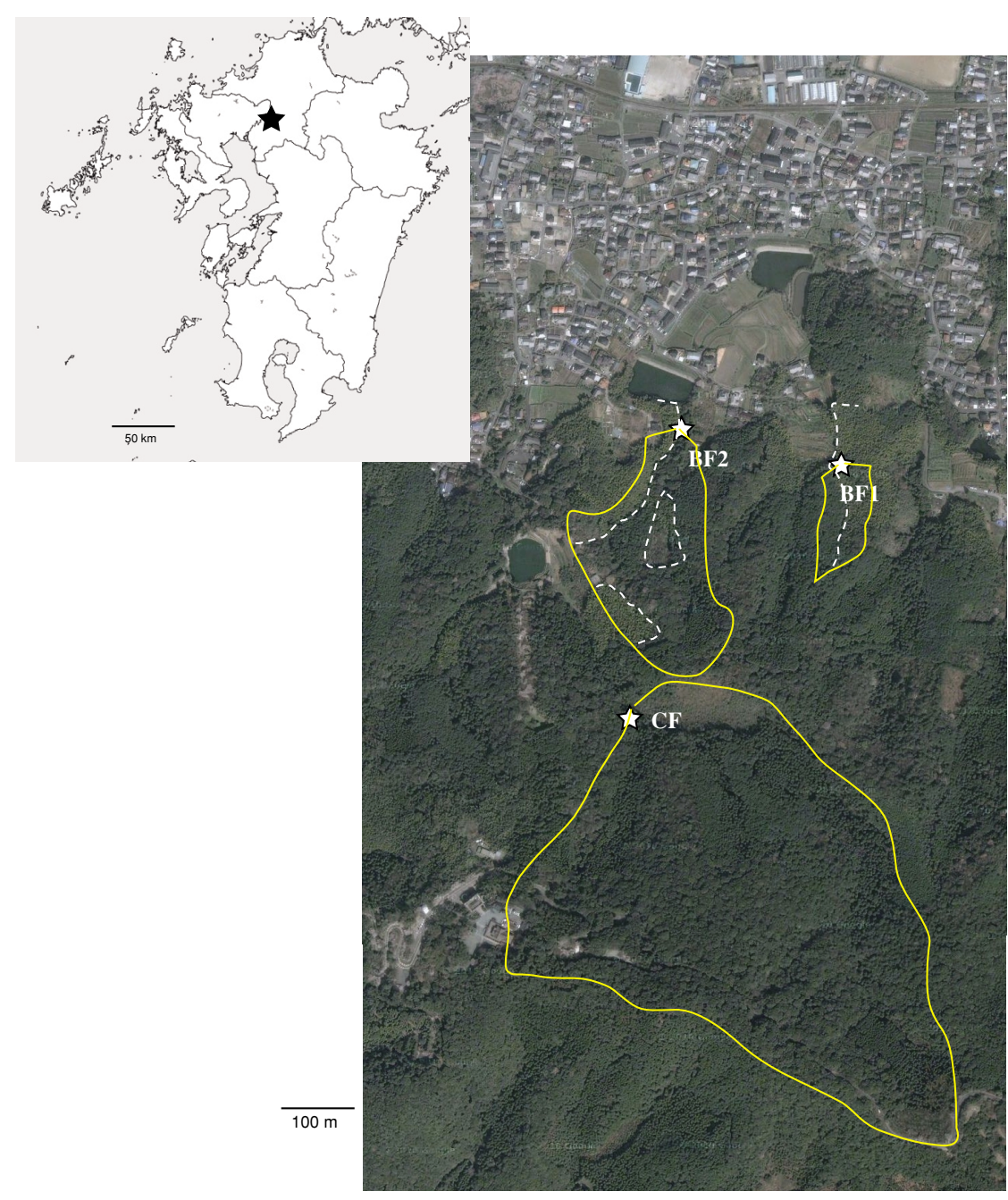

Fig. 1. An aerial photo showing the sampling sites of water. Asterisks indicate positions of water sampling. Solid lines show the watershed lines. Broken lines show the coverage of bamboo trees. Small map shows location of the studied forests in Kyushu Island (aerial photo is from Google Map).

areas of forests are invaded by bamboo in Japan, which is an important environmental problem (Isagi and Torii, 1998). This study may also provide relevant information when discussing the influence of bamboo forest expansion.

\section{METHOD}

\section{Selection of studied catchments}

We selected three catchments with varying bamboo cover on the north side of Koura-san Hill, Kurume, Fukuoka prefecture (Fig. 1): two catchments with bamboo (BF1 and BF2), and a control catchment without (CF). More than half the area of catchment BF1 is covered by bamboo and around $30 \%$ of the area of catchment BF2 is covered. In CF there is no recognizable bamboo. The three catchments are located within $1 \mathrm{~km}$ from each other on older Sangun metamorphic rock. The altitudes of BF1 and BF2 are 130-142 m above sea level (asl) and 130-152 m asl, respectively and that of CF is $141-290 \mathrm{~m}$ asl. At the lowest altitude of each catchment stream water sampling was performed (shown in asterisks in Fig. 1). The annual precipitation and mean temperature observed for the last 30 years at the nearest meteoritic station (located $7 \mathrm{~km}$ west from the studied hill) was $1850 \pm 340(\sigma) \mathrm{mm}$ and $16.4 \pm 0.6(\sigma)^{\circ} \mathrm{C}$. The soil in the forest is classified as brown forest soil. The vegetation of the three catchments is shown in Table 1. According to some of the owners of the two catchments with bamboo, it is very likely that catchments BF1 and BF2 have been left undisturbed for more than 40 years. The density population of bamboo culms exceeds $5,000 \mathrm{ha}^{-1}$, and is considered to have reached its maximum, which will provide a basis for later steady-state handling of the observed data. Catchment CF 
Table 1. Vegetation of the three catchments in the north side of Koura-san Hill

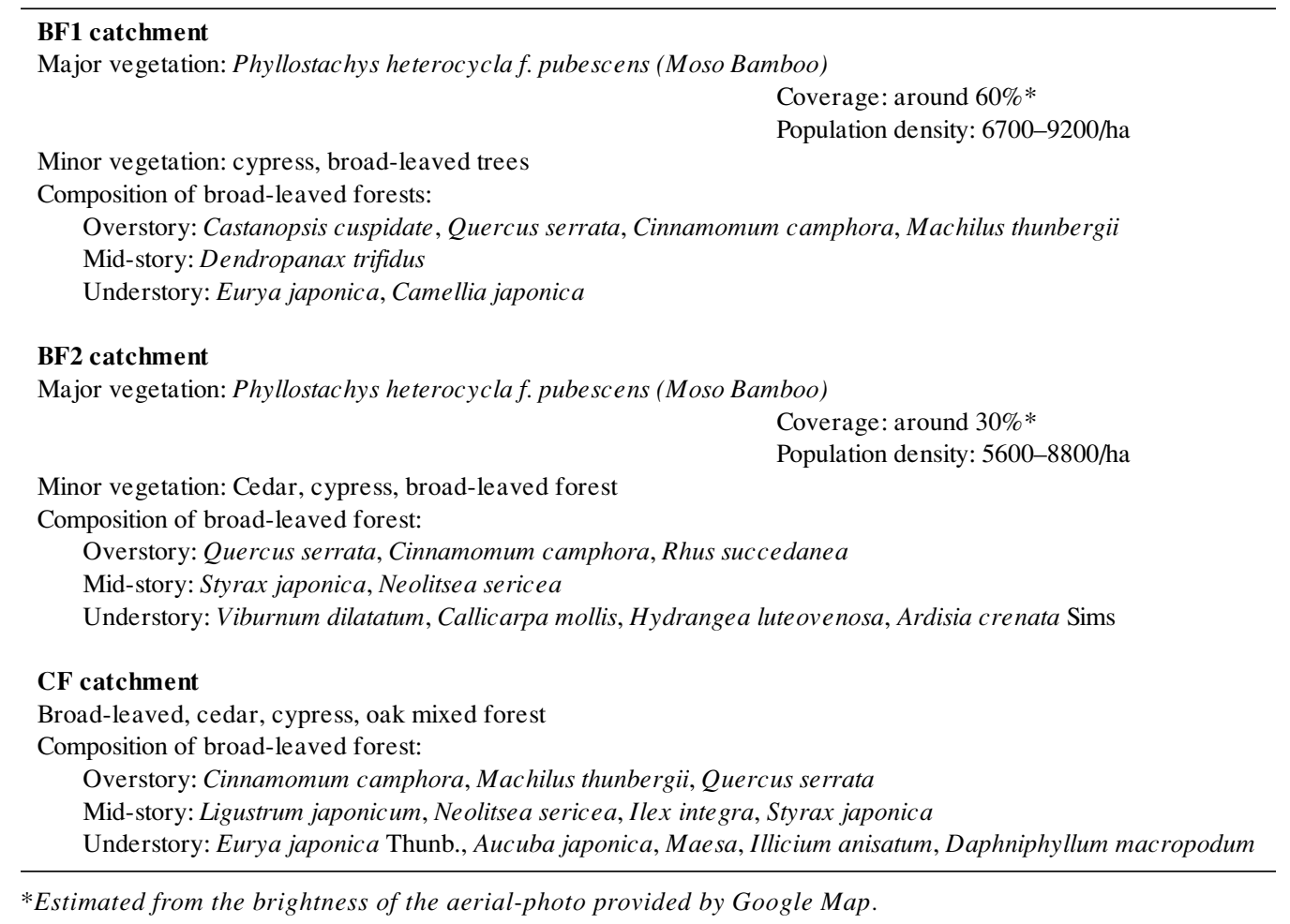

belongs to the designated natural park for hiking by Fukuoka prefecture and has long been kept undisturbed except its very top, where roadworks were carried out. The area the roadworks affected is less than a few $\%$ of the total area of the catchment. Sampling of stream water was performed every month from May 2010 to April 2011.

\section{Sampling and in-situ measurement of stream water}

During stream water sampling, $\mathrm{pH}$, water temperature, redox potential $(\mathrm{Eh})$, and electrical conductivity $(\mathrm{Ec})$ were measured by placing the corresponding probes into the stream water. Depth, width and velocity of stream water were measured to calculate water flow (simply a product of the three). Alkalinity was measured as the consumption of $0.01 \mathrm{M}$ sulfuric acid solution to decrease the $\mathrm{pH}$ to 4.8 using a portable electric balance and appropriate $\mathrm{pH}$ indicators. Water was sampled from stream water using clean polyethylene bottles. $200 \mathrm{ml}$ of water was filtered in-situ using a membrane filter cartridge (pore size $0.45 \mu \mathrm{m}$, DISMIC cellulose acetate filter, Advantec Toyo Kaisha, Ltd.) and a disposable syringe. Half of this was stored in a cool box and the other half was acidified at pH 1 in a pre-cleaned plastic bottle using nitric acid.

\section{Water sample analysis}

$\mathrm{Na}, \mathrm{Ca}, \mathrm{Mg}, \mathrm{Fe}, \mathrm{Mn}$, and $\mathrm{Al}$ in acidified samples were determined directly by inductively coupled plasma spectrometry, and $\mathrm{K}$ in acidified samples by atomic absorption spectrometry. The detection limits of trace Fe, $\mathrm{Mn}$ and $\mathrm{Al}$ are 5, 1, and $20 \mu \mathrm{g} / \mathrm{L}$, respectively. Unacidified samples were analyzed for dissolved $\mathrm{Si}$ using molybdenum yellow spectrophotometry and for $\mathrm{Cl}^{-}, \mathrm{SO}_{4}{ }^{2-}, \mathrm{NO}_{3}^{-}$ by ion chromatography.

\section{Analysis of streambed sediment samples}

To obtain geological information on the watershed, sediment was analyzed for major element and mineral composition. Sediment samples were sampled from the streambed of each sampling site, were dried, and grains passing through an 80-mesh sieve were separated for elemental analysis using X-ray fluorescence (XRF). Further grinding was carried out for analyses of mineral composition using X-ray diffraction (XRD). The intensity of the XRF measurement was calibrated against that of NIES Certified Reference Material No. 2 Pond Sediment (Okamoto, 1982) to obtain the concentration.

\section{Steady-state handling}

In general, the flux of element, $i$, in stream water is expressed as

$$
\begin{aligned}
F_{i, \text { output }}= & F_{i, \text { chemical weathering }}+F_{i, \text { atmospheric input }} \\
& +\Delta F_{i, \text { biomas }}+\Delta F_{i, \text { exchange }}+\Delta F_{i, \text { human activities }}
\end{aligned}
$$

(Braun et al., 2005). (1) 
In this study the last three terms are set to zero by assuming steady-state, that is

$$
F_{i, \text { output }}=F_{i, \text { chemical weathering }}+F_{i, \text { atmospheric input }} \cdot
$$

Considering silicate weathering, only airborne clay matters in the atmospheric input. The studied forest receives a considerable amount of loess from China, which is supposed to compose soil together with the original metamorphic rock. As far as weathering of silicate mineral is concerned, therefore, we see no point in discerning airborne silicates and original silicates. In this study we simply compare the concentration of ions after correction for evaporation as discussed later.

\section{RESULTS}

Dissolved ion data of stream water (Table 2 and Fig. 2)

Table 2 summarizes the in-situ observation data and analytical results of stream water. Water temperature was highest in August and September at the three points. The $\mathrm{pH}$ at BF1 was slightly lower than that at the other two points and significantly higher Ec data were obtained at $\mathrm{BF} 1$. When $\mathrm{pH}$ dependence of Eh values is considered, water at BF2 was significantly more reducing than that at the other two points.

The $\mathrm{Cl}^{-}$concentration shows rather a constant value, irrespective of sampling months and points. It slightly increased stepwise from February. Since the purpose of the present study is to see the chemical weathering process in the catchment, the contribution of sea salt to the dissolved concentration of constituents was corrected for $\mathrm{Cl}^{-}$concentration in water, assuming that the source of $\mathrm{Cl}^{-}$is exclusively from sea salt. This handling is supported by absence of halite in Japan. The contribution decreased in order of $\mathrm{Na}$ (45\% on average), $\mathrm{SO}_{4}{ }^{2-}$ (38\% on average), $\mathrm{Mg}, \mathrm{K}$ and $\mathrm{Ca}$ ( $<2 \%$ on average). Figure 2 shows monthly variation of some dissolved constituents.

Sea salt-corrected concentrations of $\mathrm{Na}, \mathrm{K}$, and $\mathrm{Mg}$ show a consistent relationship among the three sampling points: BF1 > BF2 > CF. The monthly profiles differ among the constituents and $\mathrm{Na}$ and $\mathrm{Mg}$ show a slightly decreasing trend from spring to winter, whereas $\mathrm{K}$ shows an increasing trend until summer. The concentrations of dissolved $\mathrm{Si}$ are stable feature like $\mathrm{Cl}^{-}$, but at $\mathrm{BF} 1$ and BF2 they were higher by twice than that at CF. Ca has the relationship of $\mathrm{BF} 1>\mathrm{CF}>\mathrm{BF} 2$ almost throughout a year. Alkalinity shows a relationship similar to that of $\mathrm{Na}, \mathrm{K}$ and $\mathrm{Mg}$, i.e., BF1 > BF2 > CF, but carries greater fluctuation (not shown in Fig. 2). Especially BF1 shows lower values from August to October than the other two points. The concentrations of $\mathrm{Mn}, \mathrm{Al}$, and $\mathrm{Fe}$ are higher at BF2 than at the other two points, although their concentrations are near the detection limit. The variation seen in
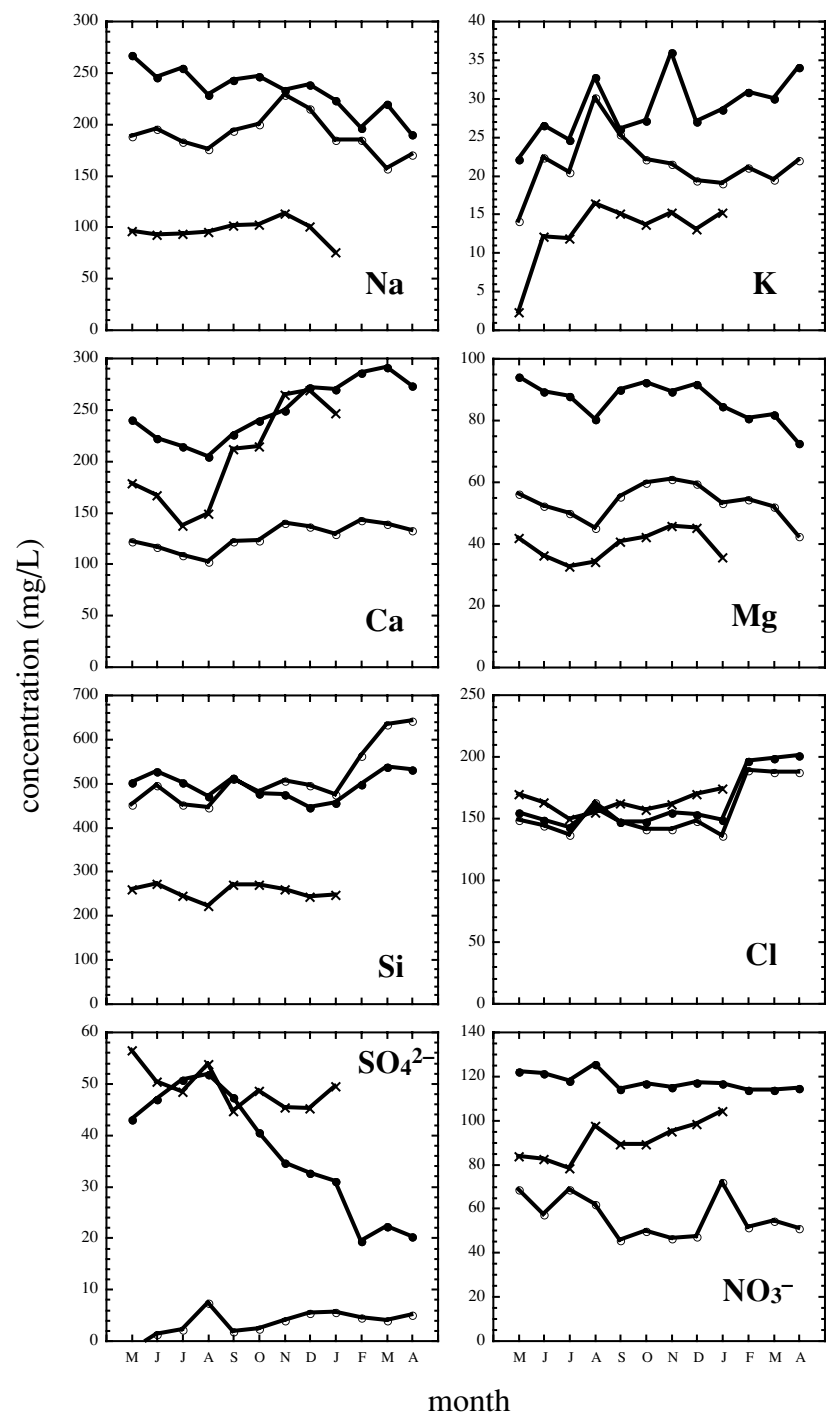

Fig. 2. Temporal variations of some dissolved ions in stream water of the three catchments. Solid circles BF1, open circles $\mathrm{BF} 2$, crosses $\mathrm{CF}$. The data of $\mathrm{Na}, \mathrm{K}, \mathrm{Ca}, \mathrm{Mg}$ and $\mathrm{SO}_{4}{ }^{2-}$ ion relate to non-sea salt component, after correction for sea salt mixing. BF1 and BF2 are the catchments with bamboo and CF is that without. See Fig. 1 for the locations of the catchments.

$\mathrm{SO}_{4}{ }^{2-}$ concentrations is greater than that of other constituents and the two catchments with bamboo tend to show smaller concentrations. The relationship in the $\mathrm{NO}_{3}{ }^{-}$ concentration is similar to that of $\mathrm{Ca}$, i.e., $\mathrm{BF} 1>\mathrm{CF}>$ $\mathrm{BF} 2$, but unlike $\mathrm{Ca}$, the concentration is rather constant from spring to autumn.

\section{Hydrological data (Table 2 and Fig. 3)}

As shown in Fig. 3a, the stream water flow observed at the three sampling points increased steadily until July and then gradually decreased. This variation closely reflects the accumulated monthly rainfall observed at 

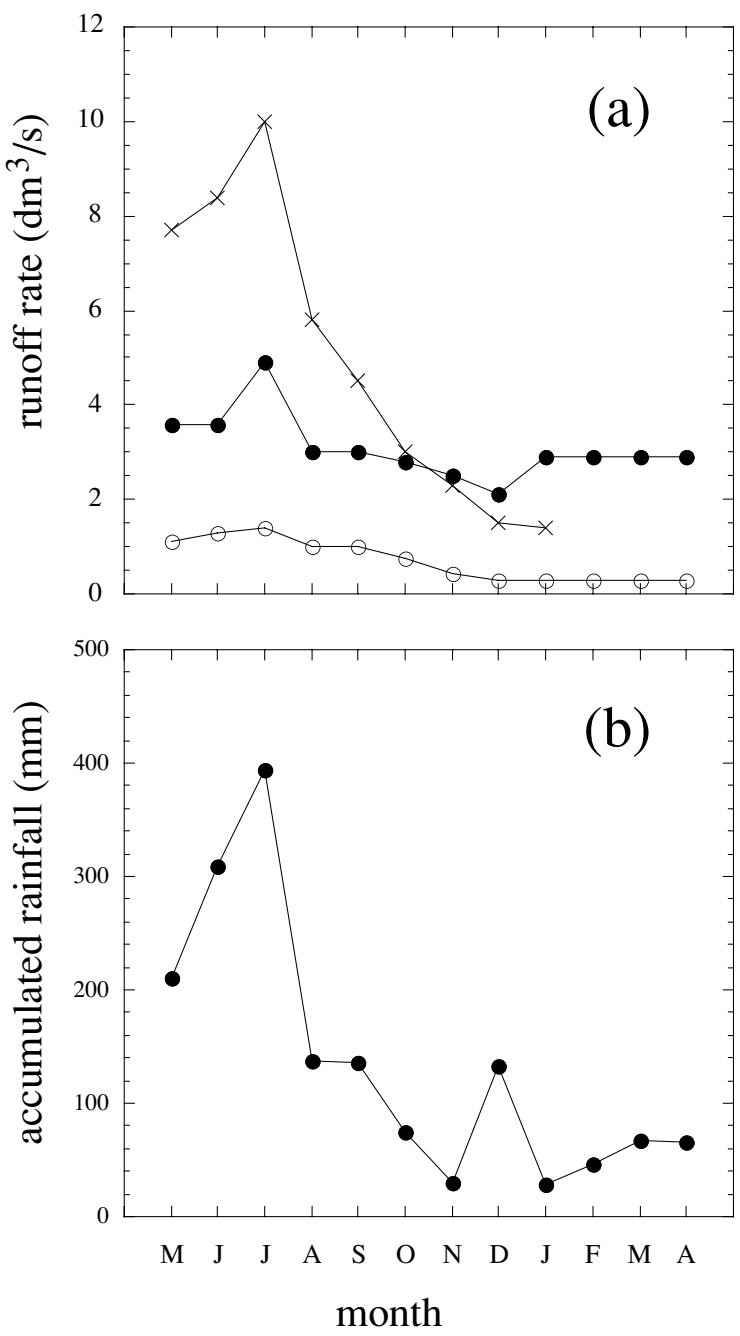

Fig. 3. Stream-water flow rate $\left(\mathrm{dm}^{3} \mathrm{~s}^{-1}\right)$ observed at the three catchments (a). Solid circles BF1, open circles BF2, crosses $C F$. Monthly accumulated rainfall $(\mathrm{mm})$ recorded at the Kurume Meteoritic Observatory (b).

Kurume Meteoritic Observatory (http://www.jma.go.jp/ $\mathrm{jma} / \mathrm{menu} / \mathrm{report}$.html). There is disagreement between the observed stream water flow and the monthly rainfall data in December, where a major rainfall took place on the 13th after sampling (11th).

\section{Streambed sediment data (Table 3 and Fig. 4)}

The results of XRF measurement on the streambed sediment samples are listed in Table 3. The compositional data are more or less similar to each other. The concentrations of $\mathrm{Fe}$ and $\mathrm{Mn}$ are somewhat lower in BF2 than those in the other site and that of $\mathrm{K}$ is the lowest in $\mathrm{CF}$. The concentration of $\mathrm{Ca}$ is in the order of $\mathrm{CF}>\mathrm{BF} 2>$ BF1. The XRD patterns (Fig. 4) show that the mineral combinations are also similar with major peaks being as-
Table 3. Analytical results (wt \%) of streambed sediment samples

\begin{tabular}{lccc}
\hline & BF1 & BF2 & CF \\
\hline $\mathrm{SiO}_{2}$ & 52 & 54 & 52 \\
$\mathrm{Al}_{2} \mathrm{O}_{3}$ & 16 & 15 & 15 \\
$\mathrm{FeO}$ & 6.2 & 5.6 & 6.1 \\
$\mathrm{~K}_{2} \mathrm{O}$ & 2.5 & 2.5 & 1.7 \\
$\mathrm{MgO}$ & 1.3 & 1.2 & 1.3 \\
$\mathrm{TiO}_{2}$ & 0.9 & 0.8 & 0.9 \\
$\mathrm{CaO}$ & 0.5 & 1.0 & 2.6 \\
$\mathrm{MnO}$ & 0.13 & 0.09 & 0.17 \\
\hline
\end{tabular}

signed to typical felsic minerals (quartz, felspar and mica) and that the relative intensity of peaks for albite and is in order of $\mathrm{CF}>\mathrm{BF} 1>\mathrm{BF} 2$. In $\mathrm{CF}$ and $\mathrm{BF} 1$ peaks of anorthite were seen. No peak of calcite was observed in any samples.

\section{DISCUSSION}

The chlorine concentration at the three catchments and its hydrological implication

Chlorine originates almost exclusively from sea salt in wet deposition (rainfall) and dry deposition, and its concentration in precipitation is largely governed by distance from the coast (Junge and Gustafson, 1957). The three catchments are located within a circle of a $250 \mathrm{~m}$ radius, $30 \mathrm{~km}$ away from the nearest seashore. The concentration of $\mathrm{Cl}^{-}$was consistent at the three sampling points, which indicates that the evapotranspiration effects of the three catchments are more or less similar. This further implies that the difference in evaporation can be neglected when discussing the dissolved-ion concentration difference among the three catchments.

The observed fairly constant $\mathrm{Cl}^{-}$concentration throughout the year for the three catchments provides us with another important implication. In general, runoff is dichotomized into surface runoff and basal runoff, and the former is chemically closer to rainfall and the latter to ground water. Ground water has a higher concentration of dissolved constituents than rainwater (Langmuir, 1997). Also, $\mathrm{Cl}^{-}$concentration in rain water tends to vary from time to time. The constant $\mathrm{Cl}^{-}$concentration in the stream water throughout the year indicates the presence of a water reservoir of a considerable capacity under ground and well-mixing of precipitation with the water in the reservoir before forming stream water. The concentration stays fairly constant even in summer with heavy rainfall, indicating efficient mixing of the waters. The increase of $\mathrm{Cl}^{-}$concentration from February to April may be attributable to very small rainfall after January, resulting in less dilution of ground water with rainfall in the catchments. 


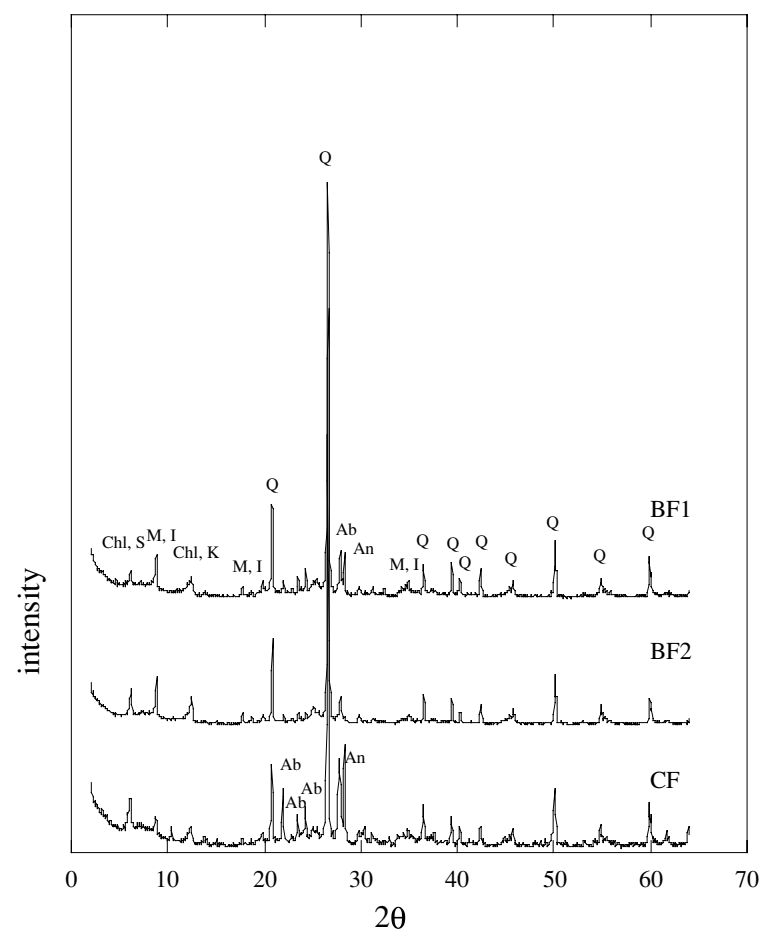

Fig. 4. X-ray diffraction spectra of the streambed sediment sampled from the three forests. $Q$ : quartz, $M$ : mica, I: illite, Ab: albite, An: anorthite, Chl: chlorite, K: kaolinite, S: smectite. See Fig. 1 for the locations of the catchments.

Weathering and dissolved ion concentration of stream water

In this study, $\mathrm{Na}, \mathrm{Mg}, \mathrm{K}, \mathrm{Si}$ and alkalinity have a similar relationship of BF1 $>\mathrm{BF} 2>\mathrm{CF}$. All five may be released from silicate rock by chemical weathering and this relationship may directly indicate the order of chemical weathering rates, as the similar level of evapotranspiration among the three catchment as mentioned in the previous section.

The three cations ( $\mathrm{Na}, \mathrm{Mg}$ and $\mathrm{K}$ ) are considered to reflect more directly the chemical weathering than other constituents, given the overall relationship of BF1 > BF2 $>\mathrm{CF}$. Inter-elemental variation may be due to their different behaviors in soil: $\mathrm{K}$ tends to be absorbed by clay minerals such as illite and soil may be its principal reservoir; $\mathrm{Mg}$ is accumulated in plant leaves and litter may be its most important reservoir; $\mathrm{Na}$ does not have a significant reservoir in soil and $\mathrm{Na}$ is the most direct indicator of weathering as in contrast to $\mathrm{K}$ and $\mathrm{Mg}$ (Braun et al., 2005; White, 2005).

The concentration of dissolved $\mathrm{Si}$ in stream water was very similar between the two catchments with bamboo (BF1 and BF2), although the greater difference was seen between the BF catchments and CF. In contrast to the above-mentioned cations, dissolution of Si may be lim- ited by the solubility of phytoliths in the catchments. Bamboo grasses incorporate $\mathrm{Si}$ and accumulate it in leaves as phytoliths. Receiving a considerable amount of leaves as litter, soil in bamboo forests may contain phytoliths at a fairy high concentration (Meunier et al., 1999; Ding et al., 2009). Because phytoliths is amorphous hydrated silica, the solubility of Si from phytoliths is higher than that in silicate minerals (Derry et al., 2005). Farmer et al. (2005) considered that the concentration of dissolved $\mathrm{Si}$ in stream water was controlled by phytolithic opal. The concentration of $\mathrm{Si}$ in the stream water from the bamboo forests is likely governed by the solubility of phytolithic material supplied as bamboo litter. This may be the reason for the observed similar Si concentration in the stream water of the two catchments of BF1 and BF2.

$\mathrm{Ca}$ is one of the major inorganic constituents in bamboo leaves, whose concentration is lower than $1 \%$ in dry weight (Ma and Takahashi, 2002). The observed doubled concentration of $\mathrm{Ca}$ at $\mathrm{BF} 1$ compared with that at BF2 may be a reflection of the doubled bamboo coverage of the BF1 catchment. The reason for the higher Ca concentration in stream water at $\mathrm{CF}$ is likely due to the more abundant presence of anorthite in its soil, since anorthite is the most readily dissolved silicate mineral (Goldich, 1938). Bicarbonate ions are responsible for the observed alkalinity of the stream water, considering the $\mathrm{pH}$ of the water. Bicarbonate ions are also products of chemical weathering of silicate rocks and the order of alkalinity, $\mathrm{BF} 1>\mathrm{BF} 2>\mathrm{CF}$, is likely to primarily be a reflection of higher rate of chemical weathering in this order. Alkalinity is consumed by acidic matter in soil, such as humic substances or the fallout of acidic aerosols, which may be the cause of the sudden decrease in values at BF1 during mid-summer following heavy rainfall before summer. The leaves in drier BF1 may start to decompose with supply of water.

The higher concentrations of $\mathrm{Mn}$ and $\mathrm{Fe}$ at $\mathrm{BF} 2$ is the result of the wetter and thus more reducing conditions with the presence of undecomposed leaves.

\section{Estimate of annual export of elements in dissolved form}

As discussed earlier, the observed rather constant $\mathrm{Cl}^{-}$ concentration in the stream water leads to the presence of capacious water reservoirs in the ground, with which stream water exchanges over a relatively short time. We have introduced the assumption that the collected stream water is a homogenized mixture of basal and surface runoff waters and that water of the same composition as surface runoff outflows as basal runoff. We are very aware that this may be an unjustified and oversimplified assumption. Nevertheless, we have dared to introduce this assumption so that we can at least estimate the minimum weathering rate.

As mentioned earlier, based on the similar $\mathrm{Cl}^{-}$con- 

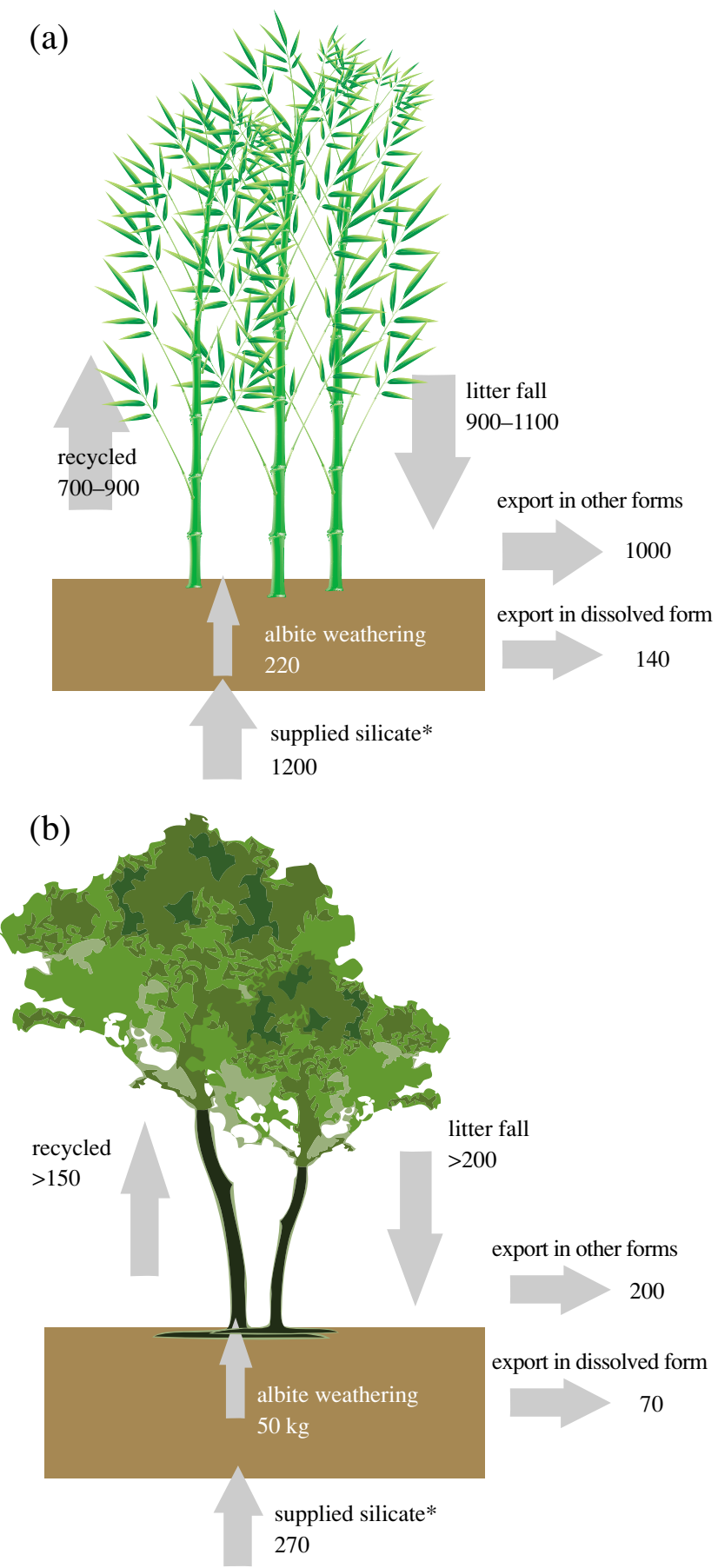

Fig. 5. Si cycles in bamboo forests (a) and bamboo-free mixed forests (b). The values in the figures are in $\mathrm{kg} \mathrm{SiO}_{2} \mathrm{ha}^{-1} \mathrm{yr}^{-1}$. *Includes airborne silicate minerals.

centrations in the stream water collected at three points, evapotranspiration is considered to have proceeded to a similar extent in the three catchments. The proportion of evaporated water can be estimated by the concentration of $\mathrm{Cl}^{-}$in the average rainfall supplied to the forest. Sasaki
Table 4. Annual flow rate of dissolved elements and ions in the three catchments

\begin{tabular}{lrrrrrc}
\hline Site & $\mathrm{Na}$ & $\mathrm{K}$ & $\mathrm{Ca}$ & $\mathrm{Mg}$ & $\mathrm{Si}$ & $\mathrm{HCO}_{3}^{-}$ \\
\hline BF1 & 110 & 12 & 100 & 40 & 220 & 280 \\
BF2 & 84 & 10 & 54 & 22 & 220 & 220 \\
$\mathrm{CF}$ & 42 & 5.2 & 80 & 16 & 110 & 160 \\
\hline
\end{tabular}

Units are $\mathrm{mmol} / \mathrm{m}^{2} / \mathrm{yr}$ for cations and silicon or meq $/ \mathrm{m}^{2} / \mathrm{yr}$ for $\mathrm{HCO}_{3}^{-}$. Values are obtained as sum of (dissolved concentration in each month) $\times$ (rainfall in each month $) \times($ evaporation residual ratio $)$ for 12 months. The evaporation residual ratio adopted is 0.3 (see text).

(2005) reported $0.78 \mathrm{mg} / \mathrm{L}$ as the weight-averaged $\mathrm{Cl}^{-}$ concentration of the precipitation in a whole year (Apr. 1998-March 1999) fallen at Fukuoka Prefecture Forestry Research and Technology Center, located ca. $2.5 \mathrm{~km}$ east of the studied forest. Also, the annual dry deposition of chlorine in the forests in the center is approximately the same as that of wet deposition (Sasaki, 2005). The average $\mathrm{Cl}^{-}$concentration of stream water is 5.8, 5.5, and 5.7 $\mathrm{mg} / \mathrm{L}$ at $\mathrm{BF} 1, \mathrm{BF} 2$, and $\mathrm{CF}$, respectively. Comparing the concentration between the runoff water and total deposition $(1.6 \mathrm{mg} / \mathrm{L}$, doubled rainfall concentration considering dry deposition), then $70 \%$ of water is estimated to have been evaporated to form the stream water, in other words, $30 \%$ of rainfall actually outflows from the catchments.

Introducing the above-mentioned two assumptions, the export of a dissolved constituent per unit area during month, $i,\left(F_{i}\right)$ can be expressed as a product of the concentration of element $\left(C_{i}\right)$, accumulated rainfall $\left(R F_{i}\right)$, and evaporation residual ratio $(1-E)$, i.e.,

$$
F_{i}\left(\mathrm{mg} / \mathrm{m}^{2}\right)=C_{i}(\mathrm{mg} / \mathrm{L}) \times R F_{i}(\mathrm{~mm}) \times(1-E) .
$$

The missing data of catchment CF, from February until April due to disappearance of stream water were compensated for using the data estimated from the following equation.

$$
\begin{aligned}
C_{i, \mathrm{CF}}= & \left.\left(C_{i, \mathrm{BF} 1}+C_{i, \mathrm{BF} 2}\right) \times C_{\mathrm{January}, \mathrm{CF}}\right) . \\
& /\left(C_{\mathrm{January}, \mathrm{BF} 1}+C_{\mathrm{January}, \mathrm{BF} 2} .\right.
\end{aligned}
$$

The monthly exports thus calculated showed the broad peak during the three months from June to April, being strongly affected by the variation of rainfall.

Annually accumulated exports of some dissolved constituents are listed in Table 4. The estimated data of the missing data for the three months contribute to only less than $15 \%$ of the annual exports, because of relatively little rainfall during the three months. As normally seen in stream water (Kobayashi, 1960), the export is enriched in $\mathrm{Na}$ and $\mathrm{Ca}$ compared with the upper crust (Rudnick 
and Gao, 2003). Since calcite was not detected in any sediment samples, $\mathrm{Na}$ and $\mathrm{Ca}$ are considered to be mainly from plagioclase.

\section{Comparison of plagioclase weathering rate with reported} values

As the studied catchments have been left almost undisturbed for more than 40 years, we introduced a steadystate assumption, whereby the annual chemical weathering rate of albite $\left(\mathrm{NaAlSi}_{3} \mathrm{O}_{8}\right)$ is set equal to the annual export of $\mathrm{Na}$ and that of anorthite $\left(\mathrm{CaAl}_{2} \mathrm{Si}_{2} \mathrm{O}_{8}\right)$ is to the annual export of $\mathrm{Ca}$, according to the next reactions (Bricker et al., 2005).

$2 \mathrm{NaAlSi}_{3} \mathrm{O}_{8}+2 \mathrm{H}^{+}+\mathrm{H}_{2} \mathrm{O}$

$=\mathrm{Al}_{2} \mathrm{Si}_{2} \mathrm{O}_{5}(\mathrm{OH})_{4}+2 \mathrm{Na}^{+}+4 \mathrm{SiO}_{2}$

$\mathrm{CaAl}_{2} \mathrm{Si}_{2} \mathrm{O}_{8}+2 \mathrm{H}^{+}+\mathrm{H}_{2} \mathrm{O}=\mathrm{Al}_{2} \mathrm{Si}_{2} \mathrm{O}_{5}(\mathrm{OH})_{4}+\mathrm{Ca}^{2+}$.

Since plagioclase is a solid solution of albite and anorthite, the sum of $\mathrm{Na}$ and $\mathrm{Ca}$ corresponds to the weathering rate of plagioclase. The plagioclase weathering rates of $\mathrm{BF} 1$, BF2 and CF are 2100, 1400 and $1200 \mathrm{~mol} \mathrm{ha}^{-1} \mathrm{yr}^{-1}$, respectively. White (2005) summarized the reported values for plagioclase weathering rate in some natural forests. They range from 44 to $316 \mathrm{~mol} \mathrm{ha}^{-1} \mathrm{yr}^{-1}$. Our estimation of the three catchments are outwith this range. Several other data for boreal lands (Moulton et al., 2000) and for equatorial rain forests (Braun et al., 2005) are also much smaller. Only the data for bamboo watersheds may be close to our values, although close comparison is limited by the different way of data presentation (Song et al., 2011).

The weathering of albite may release $\mathrm{Si}$ and $\mathrm{Na}$ (Eq. (5)) and that of anorthite may only release $\mathrm{Ca}$ (Eq. (6)). Bamboo has more than ten times the requirement for $\mathrm{Si}$ than $\mathrm{Ca}$ in molar terms (Ma and Takahashi, 2002). Considering the $\mathrm{Na}$ and $\mathrm{Ca}$ ratio in stream water (1:1 in Table 4), bamboo tends to be more deficient in Si than $\mathrm{Ca}$, and in order to absorb Si albite may selectively be dissolved by bamboo. It is interesting to note that the export rates of $\mathrm{Na}$ from the three forests are roughly proportional to the bamboo cover of the forests. The weathering rate of albite in pure bamboo stands (100\% cover) is estimated to be as great as $1800 \mathrm{~mol} \mathrm{ha}^{-1} \mathrm{yr}^{-1}$ based on the proportionality. The abnormally high weathering rate of albite in bamboo forests is likely to be due to the physiology of bamboo grasses for $\mathrm{Si}$ intake.

\section{Evaluation of Si concentration in the studied stream wa-} ter

Bluth and Kump (1994) presented the following two empirical equations to express the $\mathrm{Si}$ export by stream water as a function of rainfall.
For granitic areas:

$$
\begin{aligned}
& \log \mathrm{Si}\left(\mathrm{mol} \mathrm{km}^{-2} \mathrm{yr}^{-1}\right) \\
& =3.432+0.8489 \times \log \text { runoff }\left(\mathrm{cm} \mathrm{yr}^{-1}\right) .
\end{aligned}
$$

For basaltic areas:

$$
\begin{aligned}
& \log \mathrm{Si}\left(\mathrm{mol} \mathrm{km}^{-2} \mathrm{yr}^{-1}\right) \\
& =3.6774+0.80727 \times \log \operatorname{runoff}\left(\mathrm{cm} \mathrm{yr}^{-1}\right) .
\end{aligned}
$$

We compared the annual export data of Si with the empirical values given by the two equations. The annual accumulated rainfall observed at Kurume Observatory (from May 2010 to April 2011) was $1632.5 \mathrm{~mm}$, which corresponds to runoff of $49 \mathrm{~cm} \mathrm{yr}^{-1}$, after evaporation. Incorporating this runoff value to Eqs. (7) and (8) gives a Si export of $75 \mathrm{mmol} \mathrm{m}^{-2} \mathrm{yr}^{-1}$ for a granitic area and 110 $\mathrm{mmol} \mathrm{m} \mathrm{m}^{-2} \mathrm{yr}^{-1}$ for a basaltic area. The geology of the catchments is metamorphic rock and its composition is more granitic than basaltic based on the sediment data (Table 3 and Fig. 4). The observed Si export of $110 \mathrm{mmol}$ $\mathrm{m}^{-2} \mathrm{yr}^{-1}$ from CF compares fairly well with these empirical values, but that from the two bamboo catchments (220 mmol m${ }^{-2} \mathrm{yr}^{-1}$ ) are by about $2-3$ times higher. The high $\mathrm{Si}$ export rate of the bamboo catchments is consistent with a strong effect of bamboo-induced weathering.

Incidentally, the river water in Kyushu on average contains high amounts of $\mathrm{Si}$ and cations due to travelling over large areas of young volcanic rock and volcanic glass (Middle Pleistocene to Holocene) (Kobayashi, 1960). The geology of the studied hill consists of Paleozoic rock (Carboniferous to Permian). The volcanic glass from the younger volcanoes may increase the dissolved Si concentration of the stream water; however this fails to explain the contrast observed between the bamboo forests and the bamboo-free forest.

\section{Recycle of Si in bamboo forests (Fig. 5)}

Nagayama et al. (2006) investigated the annual silica flux of litter of two bamboo forests and non-bamboo forests in Shimane Prefecture and estimated the turnover time of $\mathrm{Si}$ in soil. They did not study the Si export from the forest system and the whole picture of the Si cycle in bamboo forests is still incomplete. The forest they studied is a typical moso forest and is considered to have reached its maximum density. We adopted their values to our studied forests to draw the dynamic picture of $\mathrm{Si}$ flow in the catchments. They reported 881 and $1088 \mathrm{~kg} \mathrm{SiO}_{2} \mathrm{ha}^{-1}$ $\mathrm{yr}^{-1}$ as litter flux for two moso-bamboo forests and 268 $\mathrm{kg} \mathrm{SiO}_{2} \mathrm{ha}^{-1} \mathrm{yr}^{-1}$ for a broad-leaved forest and $36 \mathrm{~kg} \mathrm{SiO}_{2}$ $\mathrm{ha}^{-1} \mathrm{yr}^{-1}$ for a cedar-tree forest. We adopted $1000 \pm 100$ $\mathrm{kg} \mathrm{SiO}_{2} \mathrm{ha}^{-1} \mathrm{yr}^{-1}$ as the litter flux for our bamboo stands. Because our bamboo-free catchment (CF) is a broadleaved-dominated forest with much smaller patches of ce- 
dar forest, $>200 \mathrm{~kg} \mathrm{SiO} \mathrm{ha}^{-1} \mathrm{yr}^{-1}$ was adopted for the bamboo-free forests.

Our estimated export of dissolved $\mathrm{SiO}_{2}$ from bamboo forest is $140 \mathrm{~kg} \mathrm{ha}^{-1} \mathrm{yr}^{-1}$ (from $220 \mathrm{mmol} \mathrm{m}^{-2} \mathrm{yr}^{-1}$ in Table 4). According to the weathering reaction of albite (Eq. (5)), at least $220 \mathrm{~kg} \mathrm{ha}^{-1} \mathrm{yr}^{-1}$ of $\mathrm{SiO}_{2}$ should be exported to explain the albite weathering rate, which was estimated for pure bamboo stands $\left(180 \mathrm{mmol} \mathrm{m}^{-2} \mathrm{yr}^{-1}\right)$ from the observed $\mathrm{Na}$ export (Table 4). Therefore, at least $80 \mathrm{~kg} \mathrm{ha}^{-1} \mathrm{yr}^{-1}$ of $\mathrm{SiO}_{2}$ should be exported in other forms such as leaves containing phytolithic opal. In fact, significant numbers of leaves were observed to be exported by the stream flow in both the bamboo forests (BF1 and BF2). If the composition of the upper crust (Rudnick and Gao, 2003) is assumed, silica $\left(\mathrm{SiO}_{2}\right)$ of 28 times the weight of $\mathrm{Na}$ may be exported from bamboo forests to retain the steady state. This consideration may require the value for export in non-dissolved forms to be much greater than that in dissolved form. This is possibly carried out as a direct flow of clay minerals in the course of denudation during overloaded rainfall. Putting the values together, the whole picture of the Si cycle is drawn in Fig. 5. The total export of $\mathrm{SiO}_{2}$ may amount to $1200 \mathrm{~kg}$ $\mathrm{ha}^{-1} \mathrm{yr}^{-1}$, and only one tenth may be explained by the export of dissolved $\mathrm{SiO}_{2}$. The total export of this amount should be compensated by the supply through chemical weathering of silicate minerals to keep steady state (Fig. 5a). Bamboo may prefer to take in dissolved $\mathrm{Si}$ and that most of other Si such as litter and clay may be left in soil until it is eventually decomposed or removed from the soil. The bamboo-induced weathering of plagioclase is likely to be a strategy to incorporate $\mathrm{Si}$. In fact, the $\mathrm{Si}$ inventory in soil is small compared with that incorporated by bamboo trees over the annual cycle (Nagayama et al., 2006). If recycled Si can only be supplied by plagioclase weathering, the recycle ratio of Si may be as high as about $80 \%$, intake amount and litter fall amount being compared. Again it should be noted that thus-estimated value for bamboo intake may be a minimum value.

The picture of the Si cycle in bamboo stands is compared to that in bamboo-free forests. Our estimate of the dissolved Si export in Table $4\left(110 \mathrm{mmol} \mathrm{m}^{-2} \mathrm{yr}^{-1}\right)$ corresponds to $70 \mathrm{~kg} \mathrm{SiO}_{2} \mathrm{ha}^{-1} \mathrm{yr}^{-1}$. In the same manner as for bamboo stands, the total export of about $270 \mathrm{~kg} \mathrm{ha}^{-1}$ $\mathrm{yr}^{-1}$ of $\mathrm{SiO}_{2}$ should be requested to explain the $\mathrm{Na}$ export, which then requests the same amount of $\mathrm{SiO}_{2}$ refilled by chemical weathering (Fig. 5b). Again if recycled Si can only be supplied by the albite weathering, the recycle ratio of $\mathrm{Si}$ may be higher than $75 \%$. Roughly speaking, irrespective of forest types, a similar proportion (about four fifths) of $\mathrm{Si}$ to that in litter is recycled. This is lower than the high recycle ratio of $\mathrm{Si}$ in an equatorial rain forest ecosystem (>90\%) (Alexandre et al., 1997).

\section{Conclusion}

The chemical weathering rate of plagioclase, especially albite, is discovered to be extremely higher in bamboo forests than common broad-leaved forests, and it is considered to be a result of the strategy to incorporate $\mathrm{Si}$ from the ground.

This study indicates that the expansion of bamboo forests may have hitherto unconsidered implications on the environment. The dissolved ion concentrations downstream of bamboo forests can be altered by the physiological activity of bamboo. The concentration of dissolved salts may be increased by the presence of bamboo forests, which may eventually affects the local fishery as well as agriculture.

Acknowledgments - This study has been supported by a general research grant, which is subsidized by Foundation of River \& Watershed Environment Management. We thank professor Kyoichi Ostuki, Kyushu University Forest, for his valuable advice and helpful information to this study.

\section{REFERENCES}

Akter, M. and Akagi, T. (2005) Effect of fine roots contact on plant-induced weathering of basalt. Soil Sci. Plant Nutrition 51, 861-871.

Alexandre, A., Meunier, J.-D., Colin, F. and Koud, J. M. (1997) Plant impact on the biogeochemical cycle of silicon and related weathering processes. Geochim. Cosmochim. Acta 61, 677-682.

Berner, R. A. (1992) Weathering, plants, and the long-term carbon cycle. Geochim. Cosmochim. Acta 56, 3225-3231.

Berner, R. A. (1995) Chemical weathering and its effect on atmospheric $\mathrm{CO}_{2}$ and climate. Chemical Weathering Rates of Silicate Minerals (White, A. F. and Brantley, S. L., eds.), Rev. Mineral. 31, 565-583.

Bluth, G. S. and Kump, L. R. (1994) Lithologic and climatic controls of river chemistry. Geochim. Cosmochim. Acta $\mathbf{5 8}$, 2341-2359.

Brantley, S. L., Goldhaber, M. B. and Ragnarsdottir, K. V. (2007) Crossing disciplines and scales to understand the critical zone. Elements 3, 307-314.

Braun, J. J., Ndam, J. R., Viers, J., Dupre, B., Bedimo, J. P., Freydier, R., Sigha Nkamdjou, L., Robain, H., Boeglin, J. L. and Muller, J. P. (2005) Present weathering mass balance in a tropical humid watershed: site of Nsimi (South Cameroon). Geochim. Cosmochim. Acta 69, 157-173.

Bricker, O. P., Jones, B. F. and Bowser, C. J. (2005) Massbalance approach to interpreting weathering reactions in watershed systems. Surface and Ground Water, Weathering, and Soils (Drever, J. I., ed.), Treatise on Geochemistry Vol. 5, Elsevier.

Derry, A. D., Kurtz, A. C., Ziegler, K. and Chadwick, O. A. (2005) Biological control of terrestrial silica cycling and export fluxes to watersheds. Nature 433, 728-730.

Ding, T. P., Zhou, J. X., Wan, D. F., Chen, Z. Y., Wang, C. Y. and Zhang, F. (2009) Silicon isotope fractionation in bam- 
boo and its significance to the biogeochemical cycle of silicon. Geochim. Cosmochim. Acta 72, 1381-1395.

Farmer, V. C., Delbos, E. and Miller, J. D. (2005) The role of phytolith formation and dissolution in controlling concentrations of silica in soil solutions and stream. Geoderma 127, 71-79.

Fraysse, F., Cantais, F., Pokrovsky, O. S., Schott, J. and Meunier, J. D. (2006) Aqueous reactivity of phytoliths and plant litter: Physico-chemical constraints on terrestrial biogeochemical cycle of silicon. J. Geochem. Exploration 88, 202-205.

Goldich, S. S. (1938) A study in rock weathering. J. Geol. 46, $17-58$.

Isagi, Y. and Torii, A. (1998) Range expansion and its mechanisms in a naturalized bamboo species, Phyllostachys pubescence, in Japan. J. Sustain For. 6, 127-141.

Junge, C. E. and Gustafson, P. E. (1957) On the distribution of sea salt over the United States and its removal by precipitation. Tellus 9, 164-173.

Kobayashi, J. (1960) A chemical study of the average quality and characteristics of river water of Japan. Ber. Ohara Inst. Landwirtschaft. Biol. 11, 313-358.

Langmuir, D. (1997) Chemical weathering Aqueous Environmental Geochemistry, Prentice Hall, Upper Saddle River.

Li, Z., Lin, P., He, J., Yang, Z. and Lin, Y. (2006) Silicon's organic pool and biological cycle in moso bamboo community of Wuyishan Biosphere Reserve. J. Zhejiang Univ. Sci. B7, 849-857.

Ma, J. F. and Takahashi, E. (2002) Appendix 3-D. Soil, Fertilizer, and Plant Silicon Research in Japan, Elsevier, 281 pp.
Meunier, J. D., Colin, F. and Alarcon, C. (1999) Biogenic silica storage in soils. Geology 27, 835-838.

Motomura, H., Mita, N. and Suzuki, M. (2002) Silica accumulation in long-lived leaves of Sasa veitchii (Carrière) Rehder (Poaceae-Bambusoideae). Annals Botany 90, 149-152.

Moulton, K. L., West, J. and Berner, R. A. (2000) Solute flux and mineral mass balance approaches to the quantification of plant effects on silicate weathering. Am. J. Sci. 300, 539570 .

Nagayama, Y., Kobayashi, M. and Saeki, T. (2006) Abstract. Annual Meeting of Jpn. Forest Soc., 117, 23 (in Japanese).

Okamoto, K. (ed.) (1982) Preparation, analysis and certification of pond sediment certified reference material. Res. Rep. Natl. Inst. Environ. Stud., Japan, Vol. 38.

Rudnick, R. L. and Gao, S. (2003) Composition of the continental crust. The Crust (ed. R. L. Rudnick) Vol. 3 Treatise on Geochemistry (Holland, H. D. and Turekian, K. K., eds.), 1-64, Elsevier-Pergamon, Oxford.

Sasaki, S. (2005) Dry deposition and canopy leaching in young stands of some deciduous trees and Japanese cedar. Jpn.J. For. Environ. 47, 1-7 (in Japanese).

Song, Z., Zhao, S., Zhang, Y., Hu, G., Cao, Z. and Wong, M. (2011) Plant impact on $\mathrm{CO}_{2}$ consumption by silicate weathering: the role of bamboo. Bot. Rev. 77, 208-213.

Walker, J. C. G., Hays, P. B. and Kasting, J. F. (1981) A negative feedback mechanism for the long-term stabilization of earth's surface temperature. J. Geophys. Res. 86, 97769782.

White, A. F. (2005) Natural weathering rates of silicate minerals. Surface and Ground Water, Weathering, and Soils (Drever, J. I., ed.), Treatise on Geochemistry Vol. 5, Elsevier. 